\title{
Hippocampal GABAergic Synapses Possess the Molecular Machinery for Retrograde Nitric Oxide Signaling
}

\author{
Eszter Szabadits, ${ }^{1 *}$ Csaba Cserép, ${ }^{1 *}$ Anikó Ludányi, ${ }^{1}$ István Katona, ${ }^{1}$ Javier Gracia-Llanes, ${ }^{2}$ Tamás F. Freund, ${ }^{1}$ and \\ Gábor Nyíri ${ }^{1}$ \\ ${ }^{1}$ Department of Cellular and Network Neurobiology, Institute of Experimental Medicine, Hungarian Academy of Sciences, H-1450 Budapest, Hungary, and \\ ${ }^{2}$ Departamento de Biología Celular, Facultad de Ciencias Biológicas, Universidad de Valencia, E-46100 Burjasot, Spain
}

\begin{abstract}
Nitric oxide (NO) plays an important role in synaptic plasticity as a retrograde messenger at glutamatergic synapses. Here we describe that, in hippocampal pyramidal cells, neuronal nitric oxide synthase (nNOS) is also associated with the postsynaptic active zones of GABAergic symmetrical synapses terminating on their somata, dendrites, and axon initial segments in both mice and rats. The NO receptor nitric oxide-sensitive guanylyl cyclase (NOsGC) is present in the brain in two functional subunit compositions: $\alpha_{1} \beta_{1}$ and $\alpha_{2} \beta_{1}$. The $\beta_{1}$ subunit is expressed in both pyramidal cells and interneurons in the hippocampus. Using immunohistochemistry and in situ hybridization methods, we describe that the $\alpha_{1}$ subunit is detectable only in interneurons, which are always positive for $\beta_{1}$ subunit as well; however, pyramidal cells are labeled only for $\beta_{1}$ and $\alpha_{2}$ subunits. With double-immunofluorescent staining, we also found that most cholecystokinin- and parvalbumin-positive and smaller proportion of the somatostatin- and nNOS-positive interneurons are $\alpha_{1}$ subunit positive. We also found that the $\alpha_{1}$ subunit is present in parvalbumin- and cholecystokinin-positive interneuron terminals that establish synapses on somata, dendrites, or axon initial segments. Our results demonstrate that NOsGC, composed of $\alpha_{1} \beta_{1}$ subunits, is selectively expressed in different types of interneurons and is present in their presynaptic GABAergic terminals, in which it may serve as a receptor for NO produced postsynaptically by nNOS in the very same synapse.
\end{abstract}

Key words: retrograde signaling; cGMP; GABAergic plasticity; interneuron; rat; mouse

\section{Introduction}

Nitric oxide (NO) participates in the molecular machinery of several forms of synaptic plasticity, including long-term potentiation (LTP) and long-term depression, whereby it may influence learning and memory processes (Garthwaite and Boulton, 1995; Daniel et al., 1998; Prast and Philippu, 2001; Koylu et al., 2005; Edwards and Rickard, 2007). The neuronal substrates of these processes are the networks of hippocampal pyramidal cells regulated by several different interneuron classes (Freund and Buzsaki, 1996). NO action in the brain is generally linked to retrograde signaling at glutamatergic synapses, in which $\mathrm{NO}$ is postsynaptically released and regulates presynaptic release. $\mathrm{NO}$ is generated from arginine by nitric oxide synthases (NOS-I, NOSII, and NOS-III) (Forstermann et al., 1991; Moncada et al., 1991;

\footnotetext{
Received April 27, 2007; revised June 13, 2007; accepted June 14, 2007.

This work was supported by the Howard Hughes Medical Institute, European Union Grant LSHM-CT-2004005166, Nemzeti Kutatási és Fejlesztési Programok Grant 1A/002/2004, Orszángos Tudományos Kutatási Alapprogramok Hungary Grants T46820 and F046407, Egészségügyi Tudományos Tanács Grant 474/2003, National Institutes of Health Grant NS30549, Spanish Ministerio de Ciencia y Tecnología-Fondo Europeo de Desarrollo Regional Grants BFI2001-3186 and BFI2004-00931, and Spanish Ministerio de Educación y Ciencia. We are grateful to Dr. F. J. Martínez-Guijarro for discussion at early stages of the study. We also thank Dr. Ken Mackie for the antibodies against $\mathrm{CB}_{1}$ receptors. The excellent technical assistance of Antónia Arszovszki, Katalin Lengyel, Katalin Iványi, and Győzó Goda is also gratefully acknowledged.

${ }^{*}$ E.S. and C.C. contributed equally to this work.

Correspondence should be addressed to Dr. Gábor Nyíri, Institute of Experimental Medicine, Hungarian Academy of Sciences, Szigony u. 43. H-1083 Budapest, Hungary. E-mail: nyiri@koki.hu.

DOI:10.1523/JNEUROSCI.1912-07.2007

Copyright $\odot 2007$ Society for Neuroscience $\quad 0270-6474 / 07 / 278101-11 \$ 15.00 / 0$
}

Bredt and Snyder, 1992). The calcium-dependent neuronal NOS (nNOS or NOS-I) is expressed in both a subpopulation of hippocampal interneurons (Jinno and Kosaka, 2002, 2004) and pyramidal cells (Wendland et al., 1994; Blackshaw et al., 2003), in which it can contribute to LTP (Doyle et al., 1996; Hawkins et al., 1998; Zorumski and Izumi, 1998; Bon and Garthwaite, 2003). nNOS binds to PDZ [Postsynaptic density-95 (PSD-95)/Discs large/Zona occludens-1]-domain-containing scaffold proteins in excitatory postsynaptic densities (Christopherson et al., 1999; Tochio et al., 2000).

NO induces cGMP production, which is a second-messenger molecule that exerts its effects through ion channels, protein kinases, and phosphodiesterases. cGMP also contributes to hippocampal synaptic plasticity (Zhuo et al., 1994; Arancio et al., 2001; Monfort et al., 2002). Only one of the two types of cGMPforming enzymes is sensitive to $\mathrm{NO}$, and this NO-sensitive guanylyl cyclase (NOsGC) is thought to be the principal NO receptor (Hobbs, 1997; Russwurm and Koesling, 2002; Koesling et al., 2004). In addition, in hippocampal neurons, cGMP seems to be generated only by NOsGC (Kobialka and Gorczyca, 2000; Teunissen et al., 2001; Schulz, 2005). The two functionally relevant subunit compositions in the hippocampus are $\alpha_{1} \beta_{1}$ and $\alpha_{2} \beta_{1}$. The distribution of NOsGC $\beta_{1}$ subunit and its mRNA has been reported previously (Gibb and Garthwaite, 2001; Burette et al., 2002; Ding et al., 2004; Pifarre et al., 2007), and it was shown to be localized in pyramidal cells and in some interneurons. In addition, $\alpha$ and $\beta$ subunits were found to colocalize in the same 
cells (Ding et al., 2004), but the $\alpha_{1}$ - and $\alpha_{2}$-containing complexes were not distinguished. At the subcellular level, NOsGC is primarily localized to the presynaptic active zone of excitatory terminals (Burette et al., 2002).

Here we show that nNOS is associated with the postsynaptic specialization of GABAergic synapse terminating on hippocampal pyramidal cell somata, dendrites, and axon initial segments (AISs), and NOsGC is distributed in the presynaptic GABAergic terminals in both mice and rats. In addition, we revealed that NOsGC $\alpha_{1} \beta_{1}$ is located only in interneurons, whereas $\alpha_{2}$ containing complexes are detectable only in pyramidal cells in mice and rats. Our results suggest that the GABAergic input of pyramidal cells can be retrogradely modulated through a so far unexplored nNOS-NOsGC pathway in the hippocampus, which uses a molecular composition of NO receptor distinct from that operating at glutamatergic pathways.

\section{Materials and Methods}

Animals. Sixteen adult male Wistar rats and eight adult male C57BL/6 mice (Charles River, Budapest, Hungary) in addition to two male nNOS knockout (KO) mice (Jax mice; The Jackson Laboratory, Bar Harbor, $\mathrm{ME}$ ) were anesthetized with an intraperitoneal injection of an anesthetic mixture (containing 2.5\% ketamine, $0.5 \%$ xilazin-hydrochloride, $0.25 \%$ promethazinium-chloride, $0.0025 \%$ benzetonium-chloride, and $0.002 \%$ hydrochinonum) used at $0.2 \mathrm{ml} / 100 \mathrm{~g}$ body weight. First, animals were perfused through the heart with $0.9 \% \mathrm{NaCl}$ solution followed by a fixative. These perfusions were performed differently depending on the type of immunohistochemistry or in situ hybridization that followed. In the preembedding immunogold experiments (showing synaptic nNOS gold labeling), three rats, three mice and two nNOS KO mice were perfused through the heart with a fixative containing $1 \%$ paraformaldehyde in 0.1 M phosphate buffer ( $\mathrm{PB})(\mathrm{pH} 7.4$ ) for $60 \mathrm{~min}$. In the preembedding immunoperoxidase experiments (colocalizing NOsGC $\alpha_{1}$ and $\beta_{1}$ subunits) and in the in situ hybridization experiments, seven rats and two mice were perfused with a fixative containing $4 \%$ paraformaldehyde in $0.1 \mathrm{M}$ PB for $30 \mathrm{~min}$. Similar fixative perfusion was used for three rats in the immunofluorescence experiments. All solutions used for perfusions in the in situ hybridization experiments were first treated with $0.1 \%$ diethylpyrocarbonate (DEPC) for $1 \mathrm{~h}$ and then autoclaved. In the preembedding immunoperoxidase experiments [localizing NOsGC $\alpha_{1}$ subunits at the electron microscopic (EM) level], three rats and three mice were perfused first for 2 min with a fixative containing 4\% paraformaldehyde in Na-acetate buffer, $\mathrm{pH}$ 6.0, and then with a fixative containing $4 \%$ paraformaldehyde in Borax buffer, $\mathrm{pH} 8.5$, for $40 \mathrm{~min}$. All fixative perfusions were followed by perfusion with $0.1 \mathrm{M} \mathrm{PB}$ for $10 \mathrm{~min}$, and then the brains were removed from the skull and were not postfixed. Blocks from the dorsal hippocampi were dissected and sectioned on a vibratome at $60 \mu \mathrm{m}$ thickness for immunogold and immunoperoxidase experiments, at $50 \mu \mathrm{m}$ thickness for in situ hybridization, and in the case of the fluorescent experiments at $40 \mu \mathrm{m}$ thickness, followed by washing in $0.1 \mathrm{M}$ PB. Then they were incubated in 10 and $30 \%$ sucrose for cryoprotection and freeze thawed over liquid nitrogen several times. After repeated washes in $0.1 \mathrm{M} \mathrm{PB}$, the sections were processed for immunostaining. Experiments were performed in accordance with the Institutional Ethical Codex and the Hungarian Act of Animal Care and Experimentation guidelines, which are in concert with the European Communities Council Directive of November 24, 1986 (86/609/EEC).

Preembedding immunoperoxidase staining. Incubation of sections in $1 \%$ human serum albumin (HSA) (Sigma, St. Louis, MO) diluted in Tris-buffered saline (TBS) was followed by a $48 \mathrm{~h}$ incubation in solutions of primary antibodies raised against NOsGC $\alpha_{1}$ subunit (rabbit polyclonal antibody; catalog number G4280, lot number 011K4888; 1:10,000 for the mirror experiments, 1:1000 for EM measurements; Sigma) and NOsGC $\beta_{1}$ subunit (rabbit polyclonal antibody; catalog number 160897, lot number 134521, 1:4000; Cayman Chemical, Ann Arbor, MI) diluted in TBS. After subsequent extensive washing in TBS, the sections were incubated with biotinylated anti-rabbit (goat polyclonal antibody, 1:200;
Vector Laboratories, Burlington, CA), followed by avidin-biotinylated horseradish peroxidase complex (Elite ABC, 1:300; Vector Laboratories) diluted in TBS for $3 \mathrm{~h}$. The immunoperoxidase reaction was developed using 3,3-diaminobenzidine (DAB) (Sigma) as a chromogen. In the mirror experiments, the $\mathrm{DAB}$ was intensified with ammonium nickel sulfate (DAB-Ni) in three rats. In the case of the fourth rat, after incubation in $\mathrm{ABC}$ and subsequent washes in TBS, sections were incubated in biotinyl tyramide solution (1:50, Renaissance TSA kit; PerkinElmer Life Sciences, Boston, MA) diluted in its own buffer for $15 \mathrm{~min}$, followed by washes in TBS and a second incubation in ABC, again followed by DAB-Ni development. The sections were treated with osmium tetroxide in $\mathrm{PB}$ on ice. Sections in mirror experiments were not osmicated. After that, sections were dehydrated in ascending alcohol series and propylene oxide and embedded in Durcupan (ACM; Fluka, Buchs, Switzerland). During dehydration, the sections were treated with $1 \%$ uranyl acetate in $70 \%$ ethanol for $30 \mathrm{~min}$.

Preembedding immunogold and combined immunogold-immunoperoxidase staining. To localize nNOS, first we incubated sections in 1\% HSA and then in the solution of primary antibody for nNOS (rabbit polyclonal antibody, 1:500; Zymed Laboratories, San Francisco, CA) or in the combined staining experiments in mixtures of primary antibodies for either $\mathrm{nNOS}$ and cholecystokinin (CCK) (mouse monoclonal antibody, 1:5000; CURE Digestive Diseases Research Center, Los Angeles, CA) or nNOS and parvalbumin (PV) (mouse monoclonal antibody, 1:7000; Swant, Bellinzona, Switzerland) diluted in TBS for $48 \mathrm{~h}$. After repeated washes in TBS, sections were treated with blocking solution (Gel-BS) containing $0.5 \%$ cold water fish skin gelatin (GE Healthcare, Little Chalfont, UK) and $0.5 \%$ HSA in TBS for $1 \mathrm{~h}$. This was followed by incubation with either $1 \mathrm{~nm}$ gold-conjugated anti-rabbit (goat polyclonal antibody, 1:80; GE Healthcare) or $0.8 \mathrm{~nm}$ gold-conjugated anti-rabbit (goat polyclonal antibody, 1:80; Aurion, Wageningem, The Netherlands) diluted in Gel-BS for $24 \mathrm{~h}$. After intensive washes in TBS, the sections were treated with $2 \%$ glutaraldehyde in PB for 15 min to fix the gold particles into the tissue. This was followed by washes in PB and in enhancement conditioning solution (ECS; Aurion). After this the sections were incubated in silver enhancement solution (SE-EM; Aurion) for $60 \mathrm{~min}$ at room temperature. This was followed by wash in ECS and repeated washes in PB. Then sections of single immunogold reactions were processed for osmication and dehydration as described below. The sections of the combined method were incubated with biotinylated anti-mouse (horse polyclonal antibody, 1:200; Vector Laboratories) for $24 \mathrm{~h}$, followed by incubation in Elite ABC (1:300; Vector Laboratories) diluted in TBS for $3 \mathrm{~h}$. The immunoperoxidase reaction was developed using $\mathrm{DAB}$ as chromogen. The sections were treated with osmium tetroxide in $\mathrm{PB}$ on ice. After this, sections were dehydrated in ascending alcohol series and propylene oxide and embedded in Durcupan. During dehydration, the sections were treated with $1 \%$ uranyl acetate in $70 \%$ ethanol for $30 \mathrm{~min}$. For the electron microscopic investigations, small resin embedded tissue samples were cut from the sections and glued onto plastic blocks. After this, 70and 80 -nm-thick sections were prepared using a Leica (Nussloch, Germany) EM UC6 ultramicrotome and picked up on single-slot copper grids. The sections were examined using a Hitachi (Tokyo, Japan) H-7100 electron microscope.

Double-immunofluorescent staining. Incubation of sections in $1 \%$ human serum albumin was followed by a $2 \mathrm{~d}$ incubation in mixtures of primary antibodies for either NOsGC $\alpha_{1}$ subunit (1:1000) together with CCK (1:3000), PV (1:1000), nNOS (mouse monoclonal anti-nNOS, N2280, 1:500; Sigma), or somatostatin (SOM) (MAB354, 1:70; Chemicon, Temecula, $\mathrm{CA}$ ) or for $\mathrm{nNOS}$ together with cannabinoid $\mathrm{CB}_{1}$ receptor (rabbit polyclonal antibody, 1:500) (Hajos et al., 2000) or substance $\mathrm{P}$ receptor (SPR) (AB5060, 1:5000; Chemicon). The primary antibodies were diluted in TBS. After repeated washes in TBS, the sections were incubated in mixtures of fluorescent-labeled secondary antibodies for 5 h. To detect CCK, PV, or nNOS, we used red fluorescent Alexa 594 anti-mouse IgG (1:200; Invitrogen, Carlsbad, CA). For $\mathrm{CB}_{1}$ and SPR, we used green fluorescent Alexa 488 anti-rabbit IgG (1:200; Invitrogen). For SOM, we used FITC-conjugated anti-rat IgG (1:50; Jackson ImmunoResearch, West Grove, PA). To detect the NOsGC $\alpha_{1}$ subunit antibodies, we used either green fluorescent Alexa 488 anti-rabbit IgG or red fluorescent 
Alexa 594 anti-rabbit IgG (1:200; Invitrogen). We did not use any detergent during the immunostaining. The sections were treated with $0.025 \%$ $\mathrm{CuSO}_{4}$ solution for $30 \mathrm{~min}$ to reduce autofluorescence (Schnell et al., 1999) and then were washed in TBS, transferred onto microscope slides, and covered with Vectashield (Vector Laboratories). The sections were evaluated using a Zeiss (Oberkochen, Germany) Axioplan2 microscope.

Controls. Primary antibodies were tested by the laboratories of origin (see references above), and we also found the expected labeling pattern in cortex and hippocampus. We found no specific staining pattern with the nNOS antibodies in nNOS KO mice (see Fig. 1). NOsGC antibodies were tested further in this work (see below). Secondary antibodies were extensively tested for possible cross-reactivity with the other secondary or primary antibodies, and possible tissue labeling without primary antibodies was also tested to exclude autofluorescence or specific background labeling by the secondary antibodies. No specific staining was observed under these control conditions.

Synthesis of riboprobes for NOsGC $\alpha_{1}$ and $\alpha_{2}$ subunits. Primarily nonoverlapping segments (identity ratio $<50 \%$ ) of the rat NOsGC $\alpha_{1}$ and NOsGC $\alpha_{2}$ coding sequences (GenBank accession numbers gi: 1655846 and gi:13027399 for NOsGC $\alpha_{1}$ and NOsGC $\alpha_{2}$, respectively) were amplified by reverse transcription-PCR from cDNA derived from Wistar rat hippocampal total mRNA sample. The length and the sequence of primers are listed below for both probes; numbering of the nucleotide positions starts from the beginning of the open reading frame: NOsGC $\alpha_{1}$ probe, $800 \mathrm{bp}$ from 481 to 1280 (forward primer, $5^{\prime}$-CTC AAG ATC ACG GGG GAG T; reverse primer, 5'-ACT AGC GAG GAC TGG GGT TT); NOsGC $\alpha_{2}$ probe, 903 bp from 444 to 1346 (forward primer, $5^{\prime}$ CGA GTC CTT CAG CTC TCT GG; reverse primer, 5' -TGG GAA GTA CCT TGT GGA ATG). The primers were designed using the Primer3 software (Rozen and Skaletsky, 2000). PCR products were cloned into the SmaI site of pBluescript II SK - (Fermentas, Vilnius, Lithuania). The integrity and orientation of clones were verified by sequencing. NOsGC $\alpha_{1}$ probe was linearized by $\mathrm{Xba \textrm {I }}$ and $P s t \mathrm{I}$ digestion for the antisense and sense probe, respectively. NOsGC $\alpha_{2}$ was linearized by NotI and HindIII digestion for the antisense and sense probe, respectively. The linearized template DNA was gel extracted, precipitated, resuspended in DEPCtreated $\mathrm{H}_{2} \mathrm{O}$ at a concentration of $1 \mu \mathrm{g} / \mu \mathrm{l}$, and stored at $-20^{\circ} \mathrm{C}$. In vitro transcription was performed for $2 \mathrm{~h}$ at $37^{\circ} \mathrm{C}$ in a total volume of $20 \mu \mathrm{l}$ containing $1 \mu \mathrm{g}$ of template DNA, $1 \times$ transcription buffer, $1 \times$ Digoxigenin RNA Labeling Mixture, $40 \mathrm{U}$ of RNase inhibitor, and $20 \mathrm{U}$ of T3 or T7 RNA polymerase, which was adjusted to $20 \mu \mathrm{l}$ using DEPC-free double-distilled $\mathrm{H}_{2} \mathrm{O}$. All components were from Roche Molecular Diagnostics (Mannheim, Germany). Digoxigenin-labeled riboprobes were DNase-treated and purified using the RNeasy MinElute Cleanup kit (Qiagen, Hilden, Germany). Finally, the integrity and quantity of the riboprobes were determined using gel electrophoresis.

In situ hybridization. All solutions used for in situ hybridization were first treated with $0.1 \%$ DEPC for $1 \mathrm{~h}$ and then autoclaved. Chemicals were purchased from Sigma (Budapest, Hungary), if otherwise not indicated. Incubation of the $50-\mu \mathrm{m}$-thick rat or mouse brain slices was performed in a free-floating manner in RNase-free sterile culture wells for all steps. First the sections were washed in phosphate-buffered saline (PBST, in mM: $137 \mathrm{NaCl}, 2.7 \mathrm{KCl}, 10 \mathrm{Na}_{2} \mathrm{HPO}_{4}, 2 \mathrm{KH} 2 \mathrm{PO} 4$, and $0.1 \%$ Tween 20 , $\mathrm{pH}$ 7.4) three times for $20 \mathrm{~min}$. Hybridization was then performed overnight at $60^{\circ} \mathrm{C}$ in $0.6 \mathrm{ml}$ of hybridization buffer containing the digoxigenin-labeled riboprobe $(1.2 \mu \mathrm{g} / \mathrm{ml})$. Hybridization buffer consisted of $50 \%$ formamide, $5 \times$ SSC, $1 \%$ SDS, $50 \mu \mathrm{g} / \mathrm{ml}$ yeast tRNA, and 50 $\mu \mathrm{g} / \mathrm{ml}$ heparin in DEPC-treated $\mathrm{H}_{2} \mathrm{O}$. During the overnight incubation and the after three washing steps, the sections were continuously incubated on a shaker within a humid chamber. After incubation, the sections were first washed for $30 \mathrm{~min}$ at $60^{\circ} \mathrm{C}$ in wash solution 1 (containing $50 \%$ formamide, $5 \times$ SSC, and $1 \%$ SDS in DEPC-treated $\mathrm{H}_{2} \mathrm{O}$ ) and then twice for $45 \mathrm{~min}$ at $60^{\circ} \mathrm{C}$ in wash solution 2 (containing $50 \%$ formamide and $2 \times$ SSC in DEPC-treated $\mathrm{H}_{2} \mathrm{O}$ ). The section were next washed for $5 \mathrm{~min}$ in $0.05 \mathrm{M}$ Tris-buffered saline containing $0.1 \%$ Tween 20 (TBST), pH 7.6, and then blocked in TBST containing 10\% normal goat serum (TBSTN) for $1 \mathrm{~h}$, both at room temperature. Next, sections were incubated overnight at $4{ }^{\circ} \mathrm{C}$ with sheep anti-digoxigenin $\mathrm{F}_{\mathrm{ab}}$ fragment conjugated to alkaline phosphatase (Roche Molecular Diagnostics) diluted at 1:1000 in
TBSTN. The next day, the sections were washed three times for $20 \mathrm{~min}$ in TBST and then developed with freshly prepared chromogen solution in a total volume of $10 \mathrm{ml}$, containing $3.5 \mu \mathrm{l}$ of 5-bromo-4-chloro-3-indolylphosphate and $3.5 \mu \mathrm{l}$ of nitro blue tetrazolium chloride dissolved in chromogen buffer (in mm: $100 \mathrm{NaCl}, 100$ Tris-Cl, pH 9.5; $20 \mathrm{MgCl}_{2}, 2$ (-)tetramisole hydrochloride, and $0.1 \%$ Tween 20 ). The sections were gently rinsed in $1 \mathrm{ml}$ of the above developing solution in the dark for 6-8 $\mathrm{h}$, and the reaction was stopped using PBST. Finally, the sections were washed in $0.1 \mathrm{M}$ PB three times for $10 \mathrm{~min}$ and mounted in Vectashield (Vector Laboratories) onto glass slides.

Data analyses and statistics. In the fluorescent experiments, in each of the three rats, six $40-\mu \mathrm{m}$-thick coronal sections were tested per colocalization in a systematic random manner from the rostral, medial, and caudal parts of the rostrocaudal extent of the rat dorsal hippocampus. Colocalization of antigens was investigated only when the nucleus of a cell could be detected to ensure that a large part of the cell was tested. We measured the cross-sectional area of all examined cells. Cells were sampled with the help of a grid placed over the photos of each section in a systematic random manner. Once the cells were selected, they were scrutinized individually. We used NIH ImageJ image analyzer software for measuring the cells and StatSoft (Tulsa, OK) Statistica software (version 7) for data analysis. We did not intend to define the absolute number of the examined cells in the hippocampus but performed a quantitative measurement of the ratios using Abercrombie's correction (Abercrombie, 1946).

In the immunogold experiments, after extensive testing and adjusting of reaction conditions, final measurements of gold particles were performed from serial sections from each animal, in which background labeling was minimal. Immunoparticles for nNOS were counted within the anatomically defined synaptic junctions and under other cell membrane segments adjacent to synapses, without synaptic junctions. Gold particles were considered to be associated with the cell membrane only when they were not farther away from the membrane than $40 \mathrm{~nm}$.

Because most data populations in this work did not have a Gaussian distribution according to the Shapiro-Wilk's $W$ test, we used nonparametric statistics. Two groups were compared using the nonparametric Mann-Whitney $U$ test; multiple groups of data were compared using the nonparametric Kruskal-Wallis test. The null hypothesis was rejected when the $p$ level was under 0.05 , and, in such cases, the differences were considered significant throughout this paper.

\section{Results}

nNOS is associated with the postsynaptic density of GABAergic synapses on somata, dendrites, and axon initial segments of pyramidal cells

In previous studies in the hippocampal CA1 region, the NO synthesizing enzyme nNOS was found postsynaptically in pyramidal cells in their excitatory synapses (Wendland et al., 1994; Burette et al., 2002; Blackshaw et al., 2003). However, by using a preembedding immunogold technique on mildly fixed brains, here we show for the first time that nNOS can be found not only in dendritic spines in mice and rats, but it is also localized to symmetrical GABAergic synapses on pyramidal cells. We found no labeling in nNOS KO mice (Fig. $1 A$ ), whereas, for example, somatic synapses were strongly labeled in wild-type mice (Fig. $1 B, C$ ) in the very same experiments. In addition, the labeling is not randomly associated with the pyramidal cell membrane, but it is specifically enriched in symmetrical synapses (Figs. $1 B, C$, $2 A, D-H)$ as well as in asymmetrical synapses on spines (Fig. $2 \mathrm{~B}, \mathrm{C}, \mathrm{N}, \mathrm{O})$. Our measurements of the relative linear density of labeling show that, whereas labeling density was $\sim 1.35 \pm 0.31$ gold particles per micrometer membrane (mean \pm SD) in the synaptic active zone of somatic symmetrical synapses, it was only $0.03 \pm 0.02$ gold particles per micrometer at extrasynaptic membrane domains in the vicinity of these synapses. Some labeling also occurs in the cytoplasm of pyramidal cells around cisternae of the endoplasmic reticulum, and strong labeling is detectable in 
the somata and dendrites of nNOSpositive interneurons (Fig. 2 I, dendrite d).

Two types of interneurons innervate the somata of pyramidal cells: those immunoreactive for PV establish approximately two-thirds of terminals on pyramidal cell somata, whereas CCK-positive interneurons comprise approximately one-third of somatic terminals (Nyiri et al., 2001). In mice, we tested fully reconstructed symmetrical synapses, and we found that at least $\sim 76 \%$ of these fully reconstructed somatic synapses (median of the individual percentages of 16 of 19,15 of 20 , and 16 of 21 in three mice) (Figs. $1 B, C, 2 A)$ and at least $\sim 32 \%$ of the AIS synapses (median percentage of 7 of 22,10 of 26, and 6 of 20 in three mice) (Fig. $2 E, F)$ were identified as nNOS positive on the basis of immunogold particles associated with the postsynaptic density. Supposedly, these data underestimate the number of nNOS-labeled synapses, because high concentrations of scaffolding and other proteins in the postsynaptic density make detection of its constituting proteins difficult. Because perisomatic GABAergic inhibition is brought about by three types of interneurons (CCK- and PVpositive basket cells and PV-positive axo-axonic cells), these data have strong predictive values. However, dendrite targeting interneurons are much more diverse; therefore, quantification of such synapses was not performed at the electron microscopic level. Nevertheless, many of the dendritic symmetrical synapses were also intensely positive in all three mice investigated. Similar to mice, somatic (Fig. 2G,I-K), dendritic (Fig. $2 H, L$ ), and AIS (Fig. $2 M$ ) synapses are labeled in rats as well. In rats, we also performed a direct colocalization of nNOS in reconstructed synapses of both PV-and CCK-positive terminals. We found (in all three rats) that nNOS labeling was present in postsynaptic active zone of synapses established by CCK-positive and PV-positive terminals on somata (Fig. $2 I-K$ ), in synapses established by PV-positive terminals on AISs (Fig. $2 M$ ), as well as in synapses established by both CCK-positive and -negative terminals on pyramidal cell dendrites (Fig. $2 L$ ). Because different interneurons target different pyramidal cell surface domains, this means that at least five different types of interneurons establish synapses on pyramidal cells with postsynaptically located nNOS. The distribution of the NO receptors provides additional support to this conclusion (see below).

\section{Cell type-specific expression of the mRNA of NOsGC $\alpha_{1}$ and $\alpha_{2}$ subunits in the hippocampus}

NOsGC is a heterodimeric enzyme composed of two different subunits: $\alpha\left(\alpha_{1-2}\right)$ and $\beta\left(\beta_{1-2}\right)$ (Russwurm et al., 2001; Russwurm and Koesling, 2002; Koesling et al., 2004; Krumenacker et al., 2004). The subunits initially termed $\alpha_{3}$ and $\beta_{3}$ represent the human orthologs of the $\alpha_{1}$ and $\beta_{1}$ subunits, respectively (Zabel et al., 1998). Studies have also demonstrated that, whereas $\alpha_{1}, \alpha_{2}$, and $\beta_{1}$ subunits are abundant, there is only a negligible amount of $\beta_{2}$ isoform in the brain (Burgunder and Cheung, 1994; Gibb and Garthwaite, 2001; Ding et al., 2004), and, even if it is expressed with $\alpha_{1}$ or $\alpha_{2}$ subunits, the complex is either not active (Koesling, 1999) or has very low activity (Gibb et al., 2003). In fact, knocking out $\beta_{1}$ subunit results in a lethal phenotype (Friebe et al., 2007), whereas knocking out only $\alpha_{1}$ or $\alpha_{2}$ subunits does not result in lethal phenotype (Mergia et al., 2006). Therefore, there are only two kinds of functionally important subunit compositions of NOsGC in the hippocampus that detects NO signal: $\alpha_{1} \beta_{1}$ and $\alpha_{2} \beta_{1}$ complexes. Because binding of these subunit compositions to synaptic scaffolding protein and possible differences in their regulation may differentially support signaling in neurons, here we tested which neurons express these isoforms of NOsGC. Using digoxigenin-labeled riboprobes for in situ hybridization (developed with 5-bromo-4-chloro-3-indolyl-phosphate and nitro blue tetrazolium chloride dissolved in chromogen buffer solution) in rats (Fig. 3), we found that $\alpha_{1}$ subunit mRNA was only present in interneurons (Fig. $3 A-D$ ), and these labeled neurons were found in all layers of the CA1 area. On the contrary, $\alpha_{2}$ subunit mRNA was only present in pyramidal cells of the CA1 area (Fig. $3 E, F$ ). We obtained identical results in mice (data not shown).

\section{The $\alpha_{1}$ subunit of NOsGC is present in interneurons and their terminals, but it is not detectable in pyramidal cells}

Because the mRNA of NOsGC $\alpha_{1}$ subunit is selectively present in interneurons, we performed preembedding immunoperoxidase staining to test whether the axon terminals of interneurons express the $\alpha_{1}$ subunit protein. In addition, we also tested whether its complementary $\beta_{1}$ subunit is also expressed in the very same cells.

Mice and rats showed an identical staining pattern. We found that many of the hippocampal interneurons showed strong immunostaining for the $\alpha_{1}$ subunit, and these cells could be found in all layers of the hippocampus from the alveus to the stratum (str.) lacunosum-moleculare, similar to its mRNA distribution (Fig. 4A). Occasionally, interneurons with weaker labeling were also found. In interneurons, staining appeared strongest in somata, proximal dendrites, and axons. In the light microscope, basket-like axon terminal labeling appeared in the str. pyramidale around cell bodies in both species (Fig. $4 D$, mouse, $E$, rat). Using 

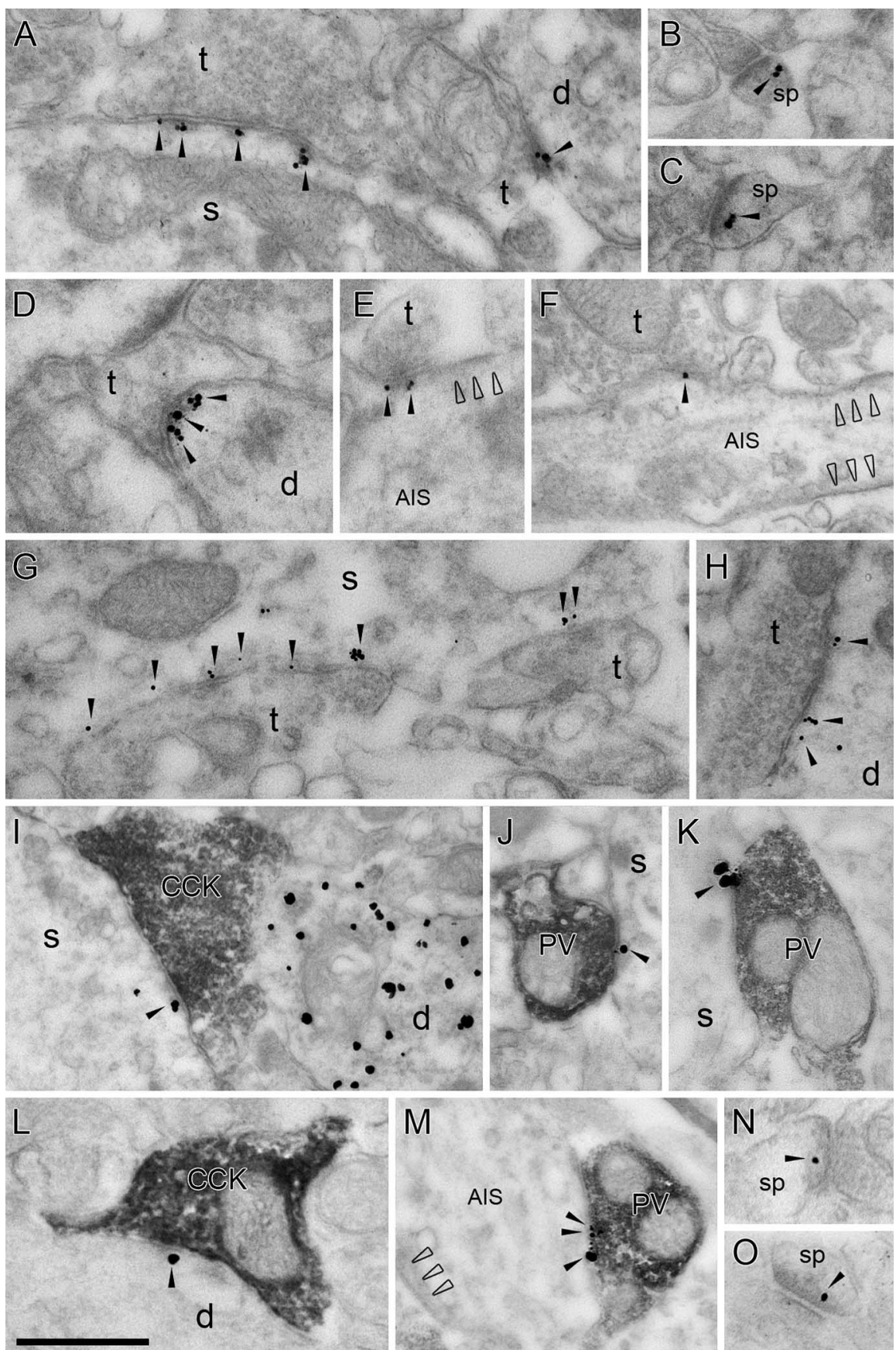

Figure 2. Electron micrographs from preembedding experiments showing nNOS immunogold labeling postsynaptically at symmetrical and asymmetrical synapses in mice and rats. Postsynaptic immunogold labeling for nNOS (arrowheads) in mice $(\boldsymbol{A}-\boldsymbol{F})$ and in rats $(\mathbf{G}-\mathbf{O})$ are present not only in asymmetrical spine (sp) synapses $(\boldsymbol{B}, \boldsymbol{C}, \mathbf{N}, \mathbf{O})$ but also attached to the postsynaptic density of symmetrical synapses, in the $C A 1$ area of the hippocampus. Labeling of symmetrical synapses confirmed in serial sections could be observed on somata $(\boldsymbol{A}, \boldsymbol{G}, \boldsymbol{I}-\boldsymbol{K})$, dendrites $(\boldsymbol{A}, \boldsymbol{D}, \boldsymbol{H}, \boldsymbol{L})$, and AlSs (typical undercoating of the membrane is indicated with open arrowheads in $\boldsymbol{E}, \boldsymbol{F}, \boldsymbol{M})$. In rats, nNOS was colocalized with $C C K(\boldsymbol{I}, \boldsymbol{L})$ and $\mathrm{PV}(\boldsymbol{J}, \boldsymbol{K}, \boldsymbol{M})$ labeling. $\boldsymbol{I}$, Strong labeling occurs in the dendrites (d) of nNOS-positive interneurons as well. t, Terminal; $s$, soma; d, dendrite; sp, spine. Scale bar, $0.5 \mu \mathrm{m}$.

electron microscopy of immunoperoxidase-stained tissue and random samples from reconstructed terminals in mice, we found that at least $\sim 79 \%$ of the reconstructed somatic terminals (median percentage of 20 of 23, 18 of 24, and 23 of 29 in three mice) (Fig. $4 F$ ) and at least $\sim 42 \%$ of the AIS terminals (median percentage of 10 of 21, 4 of 21, and 8 of 19 in three mice) (Fig. $4 H$ ) were positive for the $\alpha_{1}$ subunit of NOsGC, and many of the terminals establishing dendritic symmetrical synapses were also

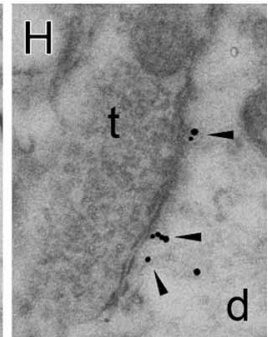

strongly positive in all three mice (Fig. $4 G)$. In rats, we also found that many of the reconstructed synaptic terminals on somata (Fig. 4I), dendrites (Fig. 4J), and AISs (Fig. $4 K$ ) were also positive for the $\alpha_{1}$ subunit. Furthermore, we also tested $\beta_{1}$ subunit labeling at the electron microscopic level in the rat and found that, as expected, many of the GABAergic terminals are also positive for the $\beta_{1}$ subunit (data not shown). This confirms our finding that the $\alpha_{1} \beta_{1}$ subunit composition of NOsGC is expressed by these GABAergic terminals, and they are in a position to detect retrograde NO signals from the pyramidal cells.

The $\alpha_{1}$ subunits always heterodimerize with $\beta_{1}$ subunits. To test whether other interneurons have abundant $\beta_{1}$ subunit containing NOsGC without the $\alpha_{1}$ subunit, we investigated the colocalization between $\alpha_{1}$ and $\beta_{1}$ subunits in rat hippocampal interneurons (Fig. $4 B, C$ ). Because both antibodies were raised in rabbit, we used the so-called mirror technique (Kosaka et al., 1985), in which cells that were cut in half on the section surfaces can be examined in adjacent sections, one incubated with $\alpha_{1}$ and the other with $\beta_{1}$ subunit antibody. As expected, $\beta_{1}$ subunits were found in both pyramidal cells (primarily dendrites) (Burette et al., 2002; Ding et al., 2004) and interneurons (primarily somata and also proximal dendrites and terminals), whereas the $\alpha_{1}$ subunit antibody labeled only interneurons. We found that $\alpha_{1}$ subunit-positive interneurons were practically always positive for the $\beta_{1}$ subunit (in four rats, 27 of 27, 41 of 42,34 of 37 , and 18 of 19), and, also, $\beta_{1}$ subunit-positive interneurons were positive for the $\alpha_{1}$ subunit (in four rats, 28 of 29,41 of 43,39 of 40 , and 16 of 17 ; some false-negative cells may occur in the sections because of the soluble nature of the $\alpha_{1}$-containing NOsGC or because of the loss of some soma tissue during sectioning). Besides confirming the specificity of the $\alpha_{1}$ subunit antibody, these results also suggest that, because no $\beta_{1}$ subunitpositive interneurons were detected without the $\alpha_{1}$ subunits, there are no interneurons that express only $\alpha_{2} \beta_{1}$ subunit composition, which is in line with our finding that $\alpha_{2}$ subunit mRNA expression was absent in interneurons.

\section{Both perisomatic and dendrite targeting GABAergic neurons contain the $\alpha_{1}$ subunit of the NOsGC}

As we have shown, many interneurons expressed the mRNA of NOsGC $\alpha_{1}$ subunit, and many of them contained NOsGC $\alpha_{1}$ subunit protein together with the $\beta_{1}$ subunit, but not all interneurons were positive. Therefore, we performed a quantitative 
immunofluorescence study to test whether major interneuron classes, including CCK-, PV-, nNOS-, or SOMpositive perisomatic or dendrite targeting interneurons, express this NO receptor. Although direct colocalization data are not available for all of these markers in the rat hippocampal CA1 region, indirect observations suggest that these four markers label different, primarily nonoverlapping populations of interneurons (Freund and Buzsaki, 1996; Jinno and Kosaka, 2000, 2002, 2004, 2006; Freund, 2003; Seress et al., 2005). The general staining patterns with these markers were similar to those reported previously. NOsGC $\alpha_{1}$ subunit staining was identical to that found with immunoperoxidase (DAB) staining (see above). No labeling could be detected in the cell nuclei. With immunofluorescent staining, we found a variable intensity of immunolabeling signal; however, we have not observed a correlation between the signal intensity and the type of interneuron markers. Thin axon-like processes could be identified in the surrounding neuropil with immunofluorescent staining as well (Fig. 5).

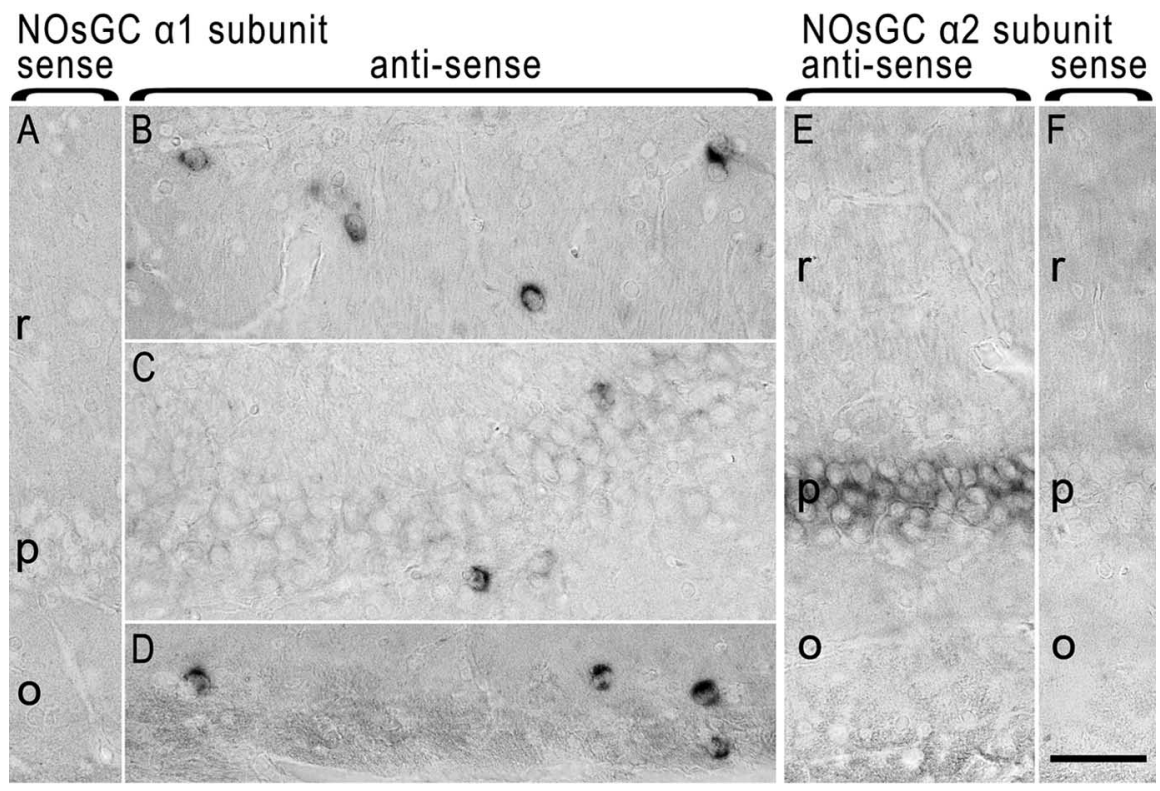

Figure 3. mRNA expression of $\operatorname{NOSGC} \alpha_{1}$ and $\alpha_{2}$ subunits in the hippocampal CA1 region. Light micrographs show a nonoverlapping mRNA labeling of the two subunits. Labeling sections with the sense probes for NOsGC $\alpha_{1}(\boldsymbol{A})$ or $\alpha_{2}(\boldsymbol{F})$ subunits provided no specific signal. Only interneurons are stained for $\operatorname{NOsGC} \alpha_{1}$ subunit in the str. radiatum $(\boldsymbol{B})$, str. pyramidale $(\boldsymbol{C})$, and oriens/ alveus (D) region. On the contrary, labeling for the $\alpha_{2}$ subunit is present only in pyramidal cells $(\boldsymbol{E})$. We found identical labeling pattern in mice (data not shown). r, Str. radiatum; p, str. pyramidale; 0 , str. oriens. Scale bar, $50 \mu \mathrm{m}$.

After investigating random samples of labeled interneurons in the CA1 area of the rat dorsal hippocampi (see Materials and Methods), we found that the median proportions are the following (in parentheses are the number of examined cells in the given colocalization from the three rats and the percentages in the animals, respectively): from all NOsGC $\alpha_{1}$ subunit-positive cells, $\sim 21 \%(n=1383 ; 23,15$, and $21 \%)$ are CCK positive (Fig. $5 A$ ), $40 \%(n=1527 ; 38,41$, and $40 \%)$ are PV positive (Fig. $5 B), 11 \%$ $(n=1322 ; 11,10$, and $20 \%)$ are nNOS positive (Fig. $5 C)$, and $\sim 7 \%(n=1599 ; 4,7$, and 7\%) are SOM-positive (Fig. $5 F)$.

Measuring it from the side of the interneuron markers, we found that the proportion of NOsGC $\alpha_{1}$-positive cells are $\sim 68 \%$ ( $n=432 ; 68,45$, and $80 \%)$ of all CCK-positive cells, $\sim 74 \%(n=$ $771 ; 74,74$, and $90 \%)$ of all PV-positive cells, $\sim 20 \%(n=756 ; 18$, 20 , and $34 \%)$ of all nNOS-positive cells, and $\sim 32 \%(n=264 ; 37$, 32 , and $31 \%$ ) of all SOM-positive cells.

Although direct and indirect data suggest that these four interneuron markers show only negligible colocalizations, little information was available about possible colocalization between nNOS- and CCK-positive cells. Because practically all CCKpositive cells are $\mathrm{CB}_{1}$ receptor-positive (Katona et al., 1999; Hajos et al., 2000), we tested whether $\mathrm{CB}_{1}$ receptor labeling and nNOS labeling can be found in the same cells (Fig. $5 E$ ), but we observed no colocalization between these two markers in the random samples ( $n=206 \mathrm{CB}_{1}$-positive cells in three rats).

Vruwink et al. (2001) suggested that there was a reciprocal chemical interaction between two inhibitory networks in the rat neocortex. One of them is positive for SPR and nNOS, and the other is substance $\mathrm{P}$ and NOsGC positive. They reported that there is a $94-95 \%$ overlap (in both directions) between nNOSpositive and SPR-positive cells in the neocortex. Therefore, besides testing NOsGC $\alpha_{1}$-positive cells for nNOS in the hippocampus, we also tested whether there is a strong overlap between nNOS- and SPR-containing cells in the hippocampus as well. Here we show that, in the hippocampal CA1 region, this overlap

is far from that observed in the neocortex. We found that, from all SPR-positive cells, $\sim 47 \%$ ( $n=709 ; 47,41$, and 50\%) were nNOS positive, whereas from all nNOS-positive cells, $\sim 43 \%$ ( $n=654$; 43, 37, and 68\%) were SPR positive (Fig. 5D).

Generation of cGMP by NOsGC appears to be a crucial step in NO signaling in the brain (Boulton et al., 1994; Ahern et al., 2002; Monfort et al., 2004; Makhinson et al., 2006). In subcortical areas, several studies demonstrated that the NO-NOsGC-cGMP pathway can either facilitate (Klyachko et al., 2001; Kraus and Prast, 2002; Li et al., 2004) or inhibit (Ozaki et al., 2000) GABAergic neurotransmission. There are at least three molecular targets that can mediate the action of cGMP in the brain. These are (1) the cyclic nucleotide gated ion channels (Zagotta and Siegelbaum, 1996), some of which have already been detected in hippocampal interneurons (Kingston et al., 1996; Maccaferri and McBain, 1996; Lorincz et al., 2002), (2) cGMP-dependent phosphodiesterases, some of which have also been shown to be expressed in these interneurons (Van Staveren et al., 2002, 2003; DomekLopacinska, 2005) and (3) the cGMP-dependent protein kinase (PKG), which may also be present in these interneurons (Kleppisch et al., 1999; Feil et al., 2005; de Vente et al., 2001, their Fig. $4 b$ ). The type II PKG is widely expressed on axon terminals and dendrites in the brain (de Vente et al., 2001), and it was also suggested that the NO-induced increase in synaptic GABA release to spinally projecting paraventricular nucleus neurons is through PKG activation targeted by cGMP (Li et al., 2004). Therefore, because these target molecules are likely present in the terminals of hippocampal interneurons, NO signal may have a strong potential and several pathways to modulate GABAergic transmission onto pyramidal cells.

\section{Correlation between the soma size of certain interneuron types and NOsGC $\alpha_{1}$ subunit content}

In many cases, the function and/or the metabolic state of a neuron can correlate with the size of its cell body; therefore, we tested whether the sizes of different interneurons correlate with their 

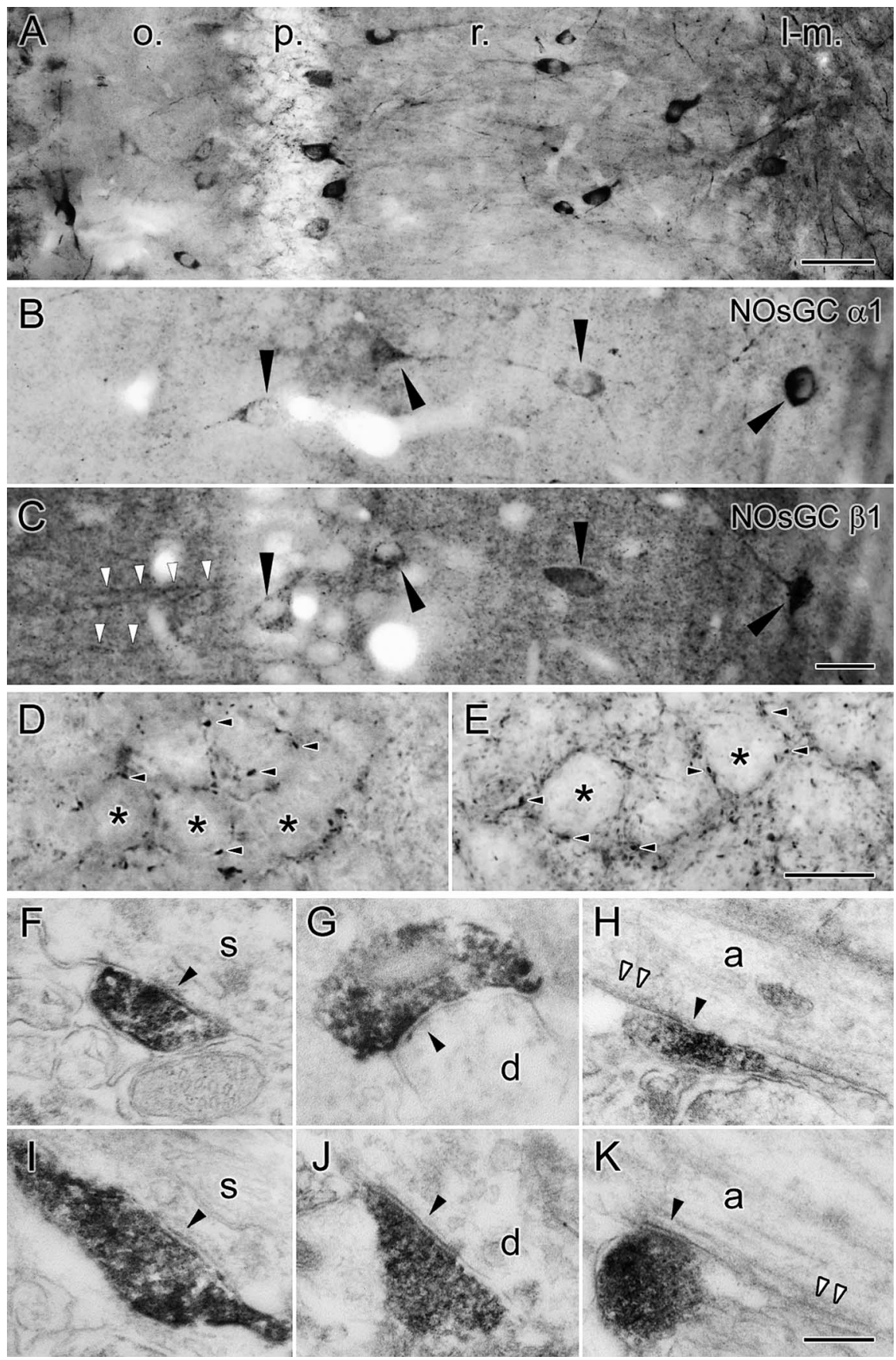

Figure 4. Light and electron micrographs from preembedding immunoperoxidase labeling for NOsGC in mice and rats. $A$, Light micrograph shows the general pattern of labeling for the $\operatorname{NOsGC} \alpha_{1}$ subunit in the different layers of the hippocampus (0., oriens; p., str. pyramidale; r., str. radiatum; I-m., str. lacunosum-moleculare). $B$, C, Photos from the "mirror experiments" showing that interneurons (arrowheads) that are cut on the surface of the sections are positive for both $\alpha_{1}$ (in $\boldsymbol{B}$ ) and $\beta_{1}$ (in $\boldsymbol{C}$ ) subunit of the NOsGC. White arrowheads show $\beta_{1}$ subunit labeling in pyramidal cell dendrites very close to the section surface. $\boldsymbol{D}, \boldsymbol{E}$, A highermagnification light micrograph of the pyramidal cell layer shows $\mathrm{NOSGC} \alpha_{1}$ subunit labeling in basket cell-like terminals (arrowheads), in both mice ( $\boldsymbol{D})$ and rats $(\boldsymbol{E})$. Asterisks indicate pyramidal cell somata. $\boldsymbol{F}-\boldsymbol{K}$, Electron micrographs of $\alpha_{1}$ subunit-labeled terminals establishing synapses on somata $(s ; \boldsymbol{F}, \boldsymbol{I})$, dendrites $(\mathrm{d} ; \boldsymbol{G}, \boldsymbol{J})$, and axon initial segments $(\mathrm{a} ; \boldsymbol{H}, \boldsymbol{K}$; white arrowheads show undercoating that is typical for AIS) in mice ( $\boldsymbol{F}-\boldsymbol{H})$ and rats (I-K). Scale bars: $\boldsymbol{A}, 50 \mu \mathrm{m} ; \boldsymbol{B}, \boldsymbol{C}, 25 \mu \mathrm{m} ; \boldsymbol{D}, \boldsymbol{E}, 10 \mu \mathrm{m} ; \boldsymbol{F}-\boldsymbol{K}, 250 \mathrm{~nm}$.

NOsGC $\alpha_{1}$ subunit content. We measured the cross-sectional area of the labeled interneurons in a given color and distributed these data into two groups according to the $\alpha_{1}$ subunit content of the cells for comparison. In the case of CCK- and SOM-positive cells, there was no correlation between NOsGC $\alpha_{1}$ subunit content and the size of the somata. Interestingly, however, we found that the cross-sectional areas of $\mathrm{PV}$ positive somata containing NOsGC $\alpha_{1}$ subunit labeling were significantly larger than those that were negative for the subunit. On average, they were 164.75 and $136.44 \mu \mathrm{m}^{2}$, respectively, which means that their area was $\sim 21 \%$ larger $(p<$ 0.001 ). (If one calculates with hypothetically spherical cells, their volume is $\sim 33 \%$ larger.) In the case of nNOS-positive interneurons, the cross-sectional areas of somata containing NOsGC $\alpha 1$ subunit labeling were significantly smaller than those that were negative for the subunit. On average, they were 121.13 and 131.81 $\mu \mathrm{m}^{2}$, respectively, which means that their area was $\sim 8 \%$ smaller $(p<0.01)$. (If, again, one calculates with hypothetically spherical cells, the difference is $\sim 12 \%$ in volume.)

\section{Discussion}

The major findings of the present study are that (1) in hippocampal pyramidal cells, nNOS is associated with the postsynaptic active zone of different GABAergic synapses, (2) NOsGC is localized in the soma-dendritic compartment as well as axon terminals of interneurons, and (3) NOsGC $\alpha_{1} \beta_{1}$ is selectively localized in interneurons, whereas principal cells express the $\alpha_{2} \beta_{1}$ subunit composition. These data suggest that $\mathrm{NO}$ can directly modify GABAergic synapses on hippocampal pyramidal cells in an activity-dependent manner in both mice and rats.

\section{Synapse-specific NO production in GABAergic synapses}

Hippocampal pyramidal cells are known to express nNOS (Wendland et al., 1994; Blackshaw et al., 2003), and its precise localization to the postsynaptic density of excitatory synapses was also described (Burette et al., 2002). The probable reason for the lack of data about its occurrence in GABAergic synapses is that its role in longterm plasticity of excitatory synapses gained more attention (see Introduction) and also because the nNOS signal can be detected only after a very mild fixation in preembedding experiments (see Materials and Methods).

Pyramidal cells of the hippocampal CA1 area are regulated by different types of interneurons (Freund and Buzsaki, 1996), which target distinct domains of pyramidal cells. Our quantitative results and colocalization experiments suggest that most of the synapses of both kinds of basket cells (PV-and CCK-containing) are nNOS positive in mice and rats. Similarly, AIS synapses established by axo-axonic cells and many of the dendritic synapses were also nNOS positive. 
NO can freely cross membranes, but the NO signal remains detectable only in a few micrometers around its site of production (Namiki et al., 2005; Iino, 2006). High-affinity binding of NO to NOsGC can lead to 200-fold activation of the enzyme (Koesling et al., 2004), and deactivation is also unexpectedly fast (Bellamy et al., 2000; Bellamy and Garthwaite, 2001). These properties suggest that NO signaling is not only fast reacting and effective but also synapse specific. Our results show that nNOS is highly enriched within GABAergic synapses (in the postsynaptic membrane) compared with adjacent nonsynaptic membrane domains, and interneuron terminals forming these synapses contain the NO receptor NOsGC. This spatially specific arrangement of molecules suggests that there is a synapse-specific retrograde signaling in these synapses, similar to what physiological data suggested in the ventral tegmental area (Nugent et al., 2007).

nNOS is activated by calcium-calmodulin under conditions of elevated intracellular calcium concentrations in the presence of arginine (Bredt and Snyder, 1992; Prast and Philippu, 2001). In excitatory synapses, the increase in local calcium concentration is maintained by synaptic NMDA receptors and other voltage-gated calcium channels. However, it is less clear which processes lead to sufficiently elevated calcium levels around GABAergic synapses postsynaptically. L- and T-type calcium channels are present around these synapses in the dendritic and perisomatic membranes (Magee et al., 1998; Kali and Freund, 2005). These channels may be activated by both dendritic and backpropagating action potentials that can lead to an increased calcium concentration, providing temporal specificity to this synapse-specific modulation. Muscarinic (especially $\mathrm{M}_{1}$ ) receptor activation, elevating local calcium concentrations, may also trigger the nNOS-NO-NOsGC-cGMP pathway, as it was shown in several paradigms (Castoldi et al., 1993; Hu and elFakahany, 1993; Ando et al., 1994; Mathes and Thompson, 1996; Liu et al., 1997; Borda et al., 2005; Cuadra and ElFakahany, 2005). In addition, muscarinic enhancement of R-type calcium currents has also been observed in hippocampal pyramidal neurons (Tai et al., 2006), whereas $M_{1}$ receptors are widely expressed in pyramidal cells (Levey et al., 1995, 1996). In vivo, $\mathrm{M}_{1}$ receptors can be activated by the septohippocampal cholinergic pathway that plays a crucial role in synaptic plasticity (Freund and Buzsaki, 1996). Together, these data suggest that a machinery that can trigger nNOS activity is present around GABAergic synapses, and it could be activated in a precisely timed manner via action potential-induced calcium influx that may need to coin-
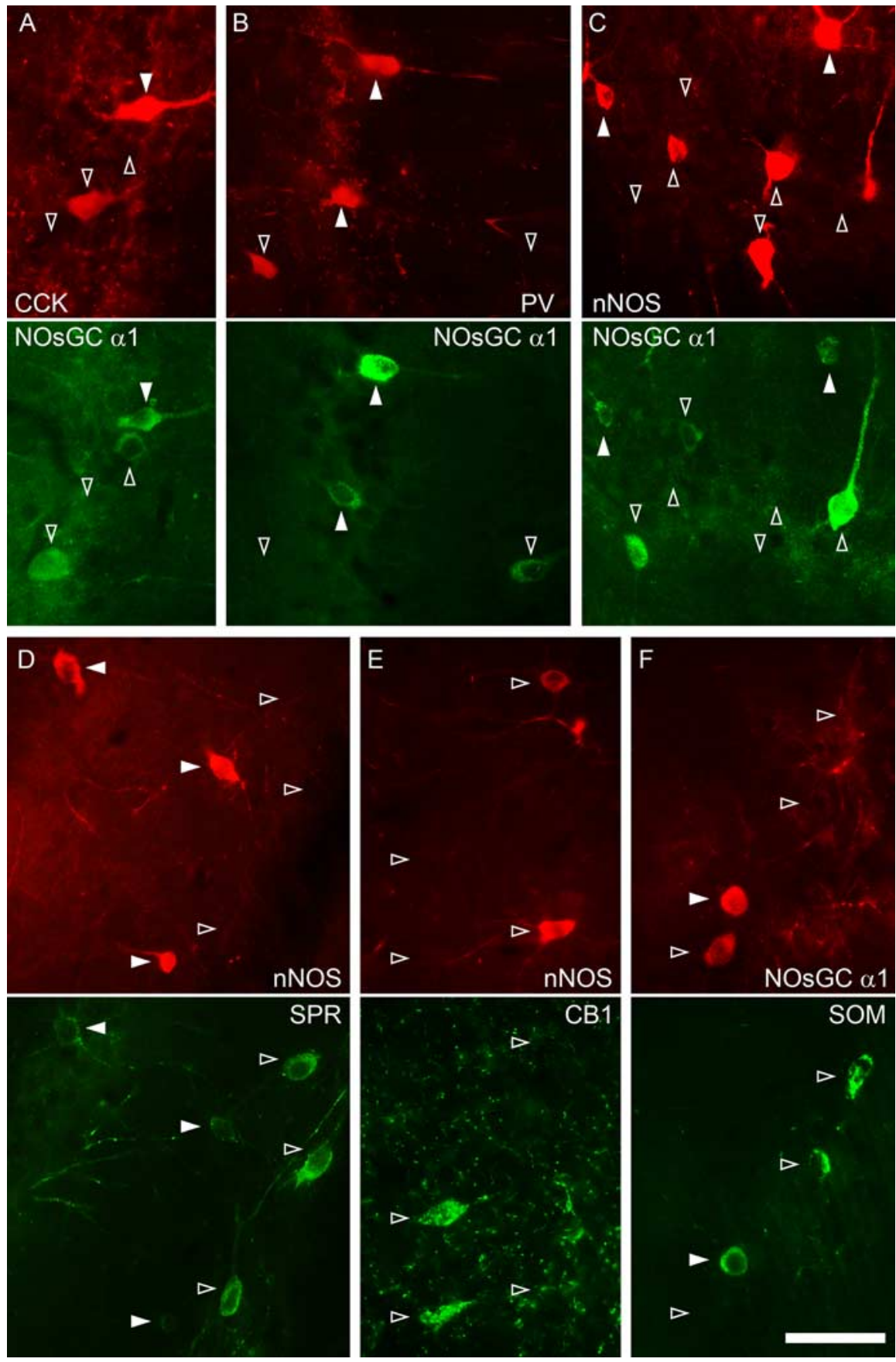

Figure 5. Fluorescent colocalization of $\operatorname{NOSGC} \alpha_{1}$ subunit and different interneuron markers in the rat hippocampal CA1 region. Fluorescent light micrographs show a partly overlapping labeling of $\mathrm{NOs} G C \alpha_{1}$ subunit with several types of interneurons that are CCK $(\boldsymbol{A}), \mathrm{PV}(\boldsymbol{B})$, nNOS $(\boldsymbol{C})$, or SOM $(\boldsymbol{F})$ positive. $\boldsymbol{D}$, nNOS and SPR show a partly overlapping labeling as well; however, $\mathrm{CB}_{1}$ and nNOS positivity could not be detected in the same cells $(\boldsymbol{E})$. Arrowheads show cells with colocalized markers, and open arrowheads show cells labeled only with one of the markers. Scale bar, $50 \mu \mathrm{m}$.

cide with muscarinic receptor-mediated elevation of the local calcium concentration.

\section{Cell type-specific expression of NOsGC subunits and its association with nNOS}

Expression of the NOsGC subunit mRNA has been reported previously in 8-d-old rat hippocampus at low magnification, showing a weak $\alpha_{1}$ and a stronger $\alpha_{2}$ and $\beta_{1}$ subunit expression (Gibb and Garthwaite, 2001). In adult rats, a large difference appears to be maintained between the $\alpha_{1}$ and $\alpha_{2}$ subunit expression at low 
magnification (Pifarre et al., 2007, their Fig. 4A-C). Our results are the first to reveal the high-resolution localization of the $\alpha$ subunits at the cellular level in the hippocampus, along with an immunohistochemical demonstration of the segregation of the $\alpha_{1}$ and $\alpha_{2}$ subunit labeling. These findings revealed that, whereas the $\alpha_{1} \beta_{1}$ subunit composition of NOsGC is expressed only in interneurons, $\alpha_{2} \beta_{1}$ complexes are restricted to pyramidal cells in both mice and rats. Our results that practically all $\alpha_{1}$ subunitpositive interneurons were positive for $\beta_{1}$ subunit and vice versa not only confirm the specificity of the antibodies but also provide immunohistochemical evidence that there are no interneurons expressing only $\alpha_{2}$ subunit-containing NOsGC.

Most perisomatic axon terminals express NOsGC $\alpha_{1}$ subunit, which makes it highly probable that both kinds of somatic inhibitory synapses are labeled in these animals. In addition, many of the axo-axonic terminals also expressed NOsGC. These data match well with those observed for nNOS labeling in perisomatic synapses, which suggest that, at any given time, expression of NO synthase and NO receptors on the two sides of the synapses do coincide. NOsGC labeling of dendritic and perisomatic GABAergic terminals in mice and rats confirmed that the NO signal can be detected in these terminals.

Although the primary structure of the two $\alpha$ subunits differ considerably in the regulatory domain, so far, the two isoforms $\alpha_{1} \beta_{1}$ and $\alpha_{2} \beta_{1}$ do not seem to show any functionally relevant differences in their regulatory properties, substrate affinity, catalytic rates, or NO sensitivity (Russwurm et al., 1998). However, a selective subcellular targeting can be mediated by the two different $\alpha$ subunits. Recent results show that, whereas the $\alpha_{1} \beta_{1}$ isoform is cytosolic, the $\alpha_{2} \beta_{1}$ isoform is associated with the PDZdomain-containing PSD-95 (Russwurm et al., 2001). In fact, recent data suggest that PSD-95 can interact with almost all members of the NO/cGMP signaling cascade, including nNOS (Brenman et al., 1996; Russwurm and Koesling, 2002; Koesling et al., 2004). Therefore, we suggest that, in the excitatory synapses of hippocampal pyramidal cells, PSD-95 binds NOsGC $\alpha_{2} \beta_{1}$ together with nNOS and NMDA receptors postsynaptically (Russwurm and Koesling, 2002; Koesling et al., 2004), whereas presynaptically $\alpha_{2} \beta_{1}$ can bind to other PDZ-domain-containing scaffolding proteins such as synapse-associated protein 97 (Muller et al., 1995). Conversely, at the GABAergic synapses terminating on pyramidal cells, PSD-95 was not yet observed, but a seven PDZ-domain-containing glutamate receptor interacting protein 1 (GRIP1) was demonstrated postsynaptically (Charych et al., 2004; Kittler et al., 2004). Therefore, GRIP1 could be a docking site for the nNOS molecules at GABAergic synapses, in which NOsGC $\alpha_{2} \beta_{1}$ isoform may also be anchored. However, as we found here, the $\alpha_{1} \beta_{1}$ isoform is present on the presynaptic side of these synapses, i.e., within the GABAergic boutons. One could also speculate that, because excitatory synapses terminating on interneurons also express PSD-95 (El-Husseini et al., 2000), absence of the $\alpha_{2}$ subunit from interneurons might ensure that these interneurons do not target NOsGC to their afferent excitatory inputs, thereby preventing a form of synaptic plasticity.

\section{nNOS- and NOsGC-mediated signaling is not equally available to all GABAergic synapses}

In situ hybridization and preembedding immunohistochemical data suggested that not all interneurons are uniformly positive for NOsGC $\alpha_{1}$ subunit. By investigating four rarely overlapping interneuron populations, our fluorescent data showed that, whereas the majority of the perisomatic CCK- and PV-positive interneurons do express NOsGC, only less than one-third of the dendrite-targeting SOM- or nNOS-positive interneurons are NOsGC positive. We also show here that CCK-positive basket cells that we identified by immunostaining for $\mathrm{CB}_{1}$ receptors never overlapped with the nNOS-containing population in the CA1 area. These data combined with our electron microscopic analysis suggest that NOsGC-positive interneurons belong to at least five different interneuron populations, because terminal labeling was shown for at least two kinds of PV-positive interneurons, in addition to the CCK, SOM, and nNOS cells. Localization of NOsGC in only a subset of these interneurons does not necessarily mean that NOsGC content would further subdivide these interneuron types into new subgroups. Instead, it can be a dynamically changing, state-dependent feature of these cells. Nonetheless, it is interesting that a significant correlation exists between the size of the PV- or nNOS-positive somata and their NOsGC $\alpha_{1}$ subunit content, which predicts that the presence of NOsGC is related to a substantial metabolic difference, even within the same interneuron population (whether causally, remains to be established).

Together, our results revealed that the molecular machinery for NO signaling is present in the majority of hippocampal GABAergic synapses, and it is different from that found in glutamatergic synapses. This molecular difference may allow a selective and differential manipulation of inhibitory and excitatory synaptic plasticity, which carries promise for future pharmacotherapy of disorders associated with an imbalance of inhibition and excitation in the cerebral cortex.

\section{References}

Abercrombie M (1946) Estimation of nuclear population from microtome sections. Anat Rec 94:239-247.

Ahern GP, Klyachko VA, Jackson MB (2002) cGMP and S-nitrosylation: two routes for modulation of neuronal excitability by NO. Trends Neurosci 25:510-517.

Ando M, Tatematsu T, Kunii S, Nagata Y (1994) The intercellular communication via nitric oxide and its regulation in coupling of cyclic GMP synthesis upon stimulation of muscarinic cholinergic receptors in rat superior cervical sympathetic ganglia. Brain Res 650:283-288.

Arancio O, Antonova I, Gambaryan S, Lohmann SM, Wood JS, Lawrence DS, Hawkins RD (2001) Presynaptic role of cGMP-dependent protein kinase during long-lasting potentiation. J Neurosci 21:143-149.

Bellamy TC, Garthwaite J (2001) Sub-second kinetics of the nitric oxide receptor, soluble guanylyl cyclase, in intact cerebellar cells. J Biol Chem 276:4287-4292.

Bellamy TC, Wood J, Goodwin DA, Garthwaite J (2000) Rapid desensitization of the nitric oxide receptor, soluble guanylyl cyclase, underlies diversity of cellular cGMP responses. Proc Natl Acad Sci USA 97:2928-2933.

Blackshaw S, Eliasson MJ, Sawa A, Watkins CC, Krug D, Gupta A, Arai T, Ferrante RJ, Snyder SH (2003) Species, strain and developmental variations in hippocampal neuronal and endothelial nitric oxide synthase clarify discrepancies in nitric oxide-dependent synaptic plasticity. Neuroscience 119:979-990.

Bon CL, Garthwaite J (2003) On the role of nitric oxide in hippocampal long-term potentiation. J Neurosci 23:1941-1948.

Borda E, Berra A, Saravia M, Ganzinelli S, Sterin-Borda L (2005) Correlations between neuronal nitric oxide synthase and muscarinic M3/M1 receptors in the rat retina. Exp Eye Res 80:391-399.

Boulton CL, Irving AJ, Southam E, Potier B, Garthwaite J, Collingridge GL (1994) The nitric oxide-cyclic GMP pathway and synaptic depression in rat hippocampal slices. Eur J Neurosci 6:1528-1535.

Bredt DS, Snyder SH (1992) Nitric oxide, a novel neuronal messenger. Neuron $8: 3-11$.

Brenman JE, Chao DS, Gee SH, McGee AW, Craven SE, Santillano DR, Wu Z, Huang F, Xia H, Peters MF, Froehner SC, Bredt DS (1996) Interaction of nitric oxide synthase with the postsynaptic density protein PSD-95 and alpha1-syntrophin mediated by PDZ domains. Cell 84:757-767.

Burette A, Zabel U, Weinberg RJ, Schmidt HH, Valtschanoff JG (2002) Syn- 
aptic localization of nitric oxide synthase and soluble guanylyl cyclase in the hippocampus. J Neurosci 22:8961-8970.

Burgunder JM, Cheung PT (1994) Expression of soluble guanylyl cyclase gene in adult rat brain. Eur J Neurosci 6:211-217.

Castoldi AF, Manzo L, Costa LG (1993) Cyclic GMP formation induced by muscarinic receptors is mediated by nitric oxide synthesis in rat cortical primary cultures. Brain Res 610:57-61.

Charych EI, Yu W, Li R, Serwanski DR, Miralles CP, Li X, Yang BY, Pinal N, Walikonis R, De Blas AL (2004) A four PDZ domain-containing splice variant form of GRIP1 is localized in GABAergic and glutamatergic synapses in the brain. J Biol Chem 279:38978-38990.

Christopherson KS, Hillier BJ, Lim WA, Bredt DS (1999) PSD-95 assembles a ternary complex with the $N$-methyl-D-aspartic acid receptor and a bivalent neuronal NO synthase PDZ domain. J Biol Chem 274:27467-27473.

Cuadra AE, El-Fakahany EE (2005) Mechanisms of M(1) muscarinic receptor-mediated up-regulation of neuronal nitric oxide synthase in N1E-115 neuroblastoma cells. Brain Res Mol Brain Res 134:198-204.

Daniel H, Levenes C, Crepel F (1998) Cellular mechanisms of cerebellar LTD. Trends Neurosci 21:401-407.

de Vente J, Asan E, Gambaryan S, Markerink-van Ittersum M, Axer H, Gallatz K, Lohmann SM, Palkovits M (2001) Localization of cGMP-dependent protein kinase type II in rat brain. Neuroscience 108:27-49.

Ding JD, Burette A, Nedvetsky PI, Schmidt HH, Weinberg RJ (2004) Distribution of soluble guanylyl cyclase in the rat brain. J Comp Neurol 472:437-448

Domek-Lopacinska K (2005) Cyclic GMP metabolism and its role in brain physiology. J Physiol Pharmacol 56 [Suppl 2]:15-34.

Doyle C, Holscher C, Rowan MJ, Anwyl R (1996) The selective neuronal NO synthase inhibitor 7-nitro-indazole blocks both long-term potentiation and depotentiation of field EPSPs in rat hippocampal CA1 in vivo. J Neurosci 16:418-424.

Edwards TM, Rickard NS (2007) New perspectives on the mechanisms through which nitric oxide may affect learning and memory processes. Neurosci Biobehav Rev 31:413-425.

El-Husseini AE, Schnell E, Chetkovich DM, Nicoll RA, Bredt DS (2000) PSD-95 involvement in maturation of excitatory synapses. Science 290:1364-1368.

Feil S, Zimmermann P, Knorn A, Brummer S, Schlossmann J, Hofmann F, Feil R (2005) Distribution of cGMP-dependent protein kinase type I and its isoforms in the mouse brain and retina. Neuroscience 135:863-868.

Forstermann U, Schmidt HH, Pollock JS, Sheng H, Mitchell JA, Warner TD, Nakane M, Murad F (1991) Isoforms of nitric oxide synthase. Characterization and purification from different cell types. Biochem Pharmacol 42:1849-1857.

Freund TF (2003) Interneuron diversity series: rhythm and mood in perisomatic inhibition. Trends Neurosci 26:489-495.

Freund TF, Buzsaki G (1996) Interneurons of the hippocampus. Hippocampus 6:347-470.

Friebe A, Mergia E, Dangel O, Lange A, Koesling D (2007) Fatal gastrointestinal obstruction and hypertension in mice lacking nitric oxide-sensitive guanylyl cyclase. Proc Natl Acad Sci USA 104:7699-7704.

Garthwaite J, Boulton CL (1995) Nitric oxide signaling in the central nervous system. Annu Rev Physiol 57:683-706.

Gibb BJ, Garthwaite J (2001) Subunits of the nitric oxide receptor, soluble guanylyl cyclase, expressed in rat brain. Eur J Neurosci 13:539-544.

Gibb BJ, Wykes V, Garthwaite J (2003) Properties of NO-activated guanylyl cyclases expressed in cells. Br J Pharmacol 139:1032-1040.

Hajos N, Katona I, Naiem SS, MacKie K, Ledent C, Mody I, Freund TF (2000) Cannabinoids inhibit hippocampal GABAergic transmission and network oscillations. Eur J Neurosci 12:3239-3249.

Hawkins RD, Son H, Arancio O (1998) Nitric oxide as a retrograde messenger during long-term potentiation in hippocampus. Prog Brain Res 118:155-172.

Hobbs AJ (1997) Soluble guanylate cyclase: the forgotten sibling. Trends Pharmacol Sci 18:484-491.

Hu J, el-Fakahany EE (1993) Role of intercellular and intracellular communication by nitric oxide in coupling of muscarinic receptors to activation of guanylate cyclase in neuronal cells. J Neurochem 61:578-585.

Iino $\mathrm{M}$ (2006) $\mathrm{Ca}^{2+}$-dependent inositol 1,4,5-trisphosphate and nitric oxide signaling in cerebellar neurons. J Pharmacol Sci 100:538-544.

Jinno S, Kosaka T (2000) Colocalization of parvalbumin and somatostatin- like immunoreactivity in the mouse hippocampus: quantitative analysis with optical dissector. J Comp Neurol 428:377-388.

Jinno S, Kosaka T (2002) Patterns of expression of calcium binding proteins and neuronal nitric oxide synthase in different populations of hippocampal GABAergic neurons in mice. J Comp Neurol 449:1-25.

Jinno S, Kosaka T (2004) Patterns of colocalization of neuronal nitric oxide synthase and somatostatin-like immunoreactivity in the mouse hippocampus: quantitative analysis with optical disector. Neuroscience 124:797-808.

Jinno S, Kosaka T (2006) Cellular architecture of the mouse hippocampus: a quantitative aspect of chemically defined GABAergic neurons with stereology. Neurosci Res 56:229-245.

Kali S, Freund TF (2005) Distinct properties of two major excitatory inputs to hippocampal pyramidal cells: a computational study. Eur J Neurosci 22:2027-2048.

Katona I, Sperlagh B, Sik A, Kafalvi A, Vizi ES, Mackie K, Freund TF (1999) Presynaptically located $\mathrm{CB}_{1}$ cannabinoid receptors regulate $\mathrm{GABA}$ release from axon terminals of specific hippocampal interneurons. J Neurosci 19:4544-4558.

Kingston PA, Zufall F, Barnstable CJ (1996) Rat hippocampal neurons express genes for both rod retinal and olfactory cyclic nucleotide-gated channels: novel targets for cAMP/cGMP function. Proc Natl Acad Sci USA 93:10440-10445.

Kittler JT, Arancibia-Carcamo IL, Moss SJ (2004) Association of GRIP1 with a $\operatorname{GABA}(\mathrm{A})$ receptor associated protein suggests a role for GRIP1 at inhibitory synapses. Biochem Pharmacol 68:1649-1654.

Kleppisch T, Pfeifer A, Klatt P, Ruth P, Montkowski A, Fassler R, Hofmann F (1999) Long-term potentiation in the hippocampal CA1 region of mice lacking cGMP-dependent kinases is normal and susceptible to inhibition of nitric oxide synthase. J Neurosci 19:48-55.

Klyachko VA, Ahern GP, Jackson MB (2001) cGMP-mediated facilitation in nerve terminals by enhancement of the spike afterhyperpolarization. Neuron 31:1015-1025.

Kobialka M, Gorczyca WA (2000) Particulate guanylyl cyclases: multiple mechanisms of activation. Acta Biochim Pol 47:517-528.

Koesling D (1999) Studying the structure and regulation of soluble guanylyl cyclase. Methods 19:485-493.

Koesling D, Russwurm M, Mergia E, Mullershausen F, Friebe A (2004) Nitric oxide-sensitive guanylyl cyclase: structure and regulation. Neurochem Int 45:813-819.

Kosaka T, Kosaka K, Tateishi K, Hamaoka Y, Yanaihara N, Wu JY, Hama K (1985) GABAergic neurons containing CCK-8-like and/or VIP-like immunoreactivities in the rat hippocampus and dentate gyrus. J Comp Neurol 239:420-430.

Koylu EO, Kanit L, Taskiran D, Dagci T, Balkan B, Pogun S (2005) Effects of nitric oxide synthase inhibition on spatial discrimination learning and central DA2 and mACh receptors. Pharmacol Biochem Behav 81:32-40.

Kraus MM, Prast H (2002) Involvement of nitric oxide, cyclic GMP and phosphodiesterase 5 in excitatory amino acid and GABA release in the nucleus accumbens evoked by activation of the hippocampal fimbria. Neuroscience 112:331-343.

Krumenacker JS, Hanafy KA, Murad F (2004) Regulation of nitric oxide and soluble guanylyl cyclase. Brain Res Bull 62:505-515.

Levey AI (1996) Muscarinic acetylcholine receptor expression in memory circuits: implications for treatment of Alzheimer disease. Proc Natl Acad Sci USA 93:13541-13546.

Levey AI, Edmunds SM, Koliatsos V, Wiley RG, Heilman CJ (1995) Expression of $\mathrm{m} 1-\mathrm{m} 4$ muscarinic acetylcholine receptor proteins in rat hippocampus and regulation by cholinergic innervation. J Neurosci 15:4077-4092.

Li DP, Chen SR, Finnegan TF, Pan HL (2004) Signalling pathway of nitric oxide in synaptic GABA release in the rat paraventricular nucleus. J Physiol (Lond) 554:100-110.

Liu C, Ding JM, Faiman LE, Gillette MU (1997) Coupling of muscarinic cholinergic receptors and cGMP in nocturnal regulation of the suprachiasmatic circadian clock. J Neurosci 17:659-666.

Lorincz A, Notomi T, Tamas G, Shigemoto R, Nusser Z (2002) Polarized and compartment-dependent distribution of $\mathrm{HCN} 1$ in pyramidal cell dendrites. Nat Neurosci 5:1185-1193.

Maccaferri G, McBain CJ (1996) The hyperpolarization-activated current (Ih) and its contribution to pacemaker activity in rat CAl hippocampal stratum oriens-alveus interneurones. J Physiol (Lond) 497:119-130. 
Magee J, Hoffman D, Colbert C, Johnston D (1998) Electrical and calcium signaling in dendrites of hippocampal pyramidal neurons. Annu Rev Physiol 60:327-346.

Makhinson M, Opazo P, Carlisle HJ, Godsil B, Grant SG, O’Dell TJ (2006) A novel role for cyclic guanosine $3^{\prime}, 5^{\prime}$ monophosphate signaling in synaptic plasticity: a selective suppressor of protein kinase A-dependent forms of long-term potentiation. Neuroscience 140:415-431.

Mathes C, Thompson SH (1996) The nitric oxide/cGMP pathway couples muscarinic receptors to the activation of $\mathrm{Ca}^{2+}$ influx. J Neurosci 16:1702-1709.

Mergia E, Friebe A, Dangel O, Russwurm M, Koesling D (2006) Spare guanylyl cyclase NO receptors ensure high NO sensitivity in the vascular system. J Clin Invest 116:1731-1737.

Moncada S, Palmer RM, Higgs EA (1991) Nitric oxide: physiology, pathophysiology, and pharmacology. Pharmacol Rev 43:109-142.

Monfort P, Munoz MD, Kosenko E, Felipo V (2002) Long-term potentiation in hippocampus involves sequential activation of soluble guanylate cyclase, cGMP-dependent protein kinase, and cGMP-degrading phosphodiesterase. J Neurosci 22:10116-10122.

Monfort P, Munoz MD, Kosenko E, Llansola M, Sanchez-Perez A, Cauli O, Felipo V (2004) Sequential activation of soluble guanylate cyclase, protein kinase G and cGMP-degrading phosphodiesterase is necessary for proper induction of long-term potentiation in CAl of hippocampus. Alterations in hyperammonemia. Neurochem Int 45:895-901.

Muller BM, Kistner U, Veh RW, Cases-Langhoff C, Becker B, Gundelfinger ED, Garner CC (1995) Molecular characterization and spatial distribution of SAP97, a novel presynaptic protein homologous to SAP90 and the Drosophila discs-large tumor suppressor protein. J Neurosci 15:2354-2366.

Namiki S, Kakizawa S, Hirose K, Iino M (2005) NO signalling decodes frequency of neuronal activity and generates synapse-specific plasticity in mouse cerebellum. J Physiol (Lond) 566:849-863.

Nugent FS, Penick EC, Kauer JA (2007) Opioids block long-term potentiation of inhibitory synapses. Nature 446:1086-1090.

Nyiri G, Freund TF, Somogyi P (2001) Input-dependent synaptic targeting of alpha(2)-subunit-containing GABA(A) receptors in synapses of hippocampal pyramidal cells of the rat. Eur J Neurosci 13:428-442.

Ozaki M, Shibuya I, Kabashima N, Isse T, Noguchi J, Ueta Y, Inoue Y, Shigematsu A, Yamashita H (2000) Preferential potentiation by nitric oxide of spontaneous inhibitory postsynaptic currents in rat supraoptic neurones. J Neuroendocrinol 12:273-281.

Pifarre P, Garcia A, Mengod G (2007) Species differences in the localization of soluble guanylyl cyclase subunits in monkey and rat brain. J Comp Neurol 500:942-957.

Prast H, Philippu A (2001) Nitric oxide as modulator of neuronal function. Prog Neurobiol 64:51-68.

Rozen S, Skaletsky H (2000) Primer3 on the WWW for general users and for biologist programmers. Methods Mol Biol 132:365-386.

Russwurm M, Koesling D (2002) Isoforms of NO-sensitive guanylyl cyclase. Mol Cell Biochem 230:159-164.
Russwurm M, Behrends S, Harteneck C, Koesling D (1998) Functional properties of a naturally occurring isoform of soluble guanylyl cyclase. Biochem J 335:125-130.

Russwurm M, Wittau N, Koesling D (2001) Guanylyl cyclase/PSD-95 interaction: targeting of the nitric oxide-sensitive alpha2beta1 guanylyl cyclase to synaptic membranes. J Biol Chem 276:44647-44652.

Schnell SA, Staines WA, Wessendorf MW (1999) Reduction of lipofuscinlike autofluorescence in fluorescently labeled tissue. J Histochem Cytochem 47:719-730.

Schulz S (2005) C-type natriuretic peptide and guanylyl cyclase B receptor. Peptides 26:1024-1034.

Seress L, Abraham H, Hajnal A, Lin H, Totterdell S (2005) NOS-positive local circuit neurons are exclusively axo-dendritic cells both in the neoand archi-cortex of the rat brain. Brain Res 1056:183-190.

Tai C, Kuzmiski JB, MacVicar BA (2006) Muscarinic enhancement of R-type calcium currents in hippocampal CA1 pyramidal neurons. J Neurosci 26:6249-6258.

Teunissen C, Steinbusch H, Markerink-van Ittersum M, Koesling D, de Vente J (2001) Presence of soluble and particulate guanylyl cyclase in the same hippocampal astrocytes. Brain Res 891:206-212.

Tochio H, Mok YK, Zhang Q, Kan HM, Bredt DS, Zhang M (2000) Formation of nNOS/PSD-95 PDZ dimer requires a preformed beta-finger structure from the nNOS PDZ domain. J Mol Biol 303:359-370.

Van Staveren WC, Glick J, Markerink-van Ittersum M, Shimizu M, Beavo JA, Steinbusch HW, de Vente J (2002) Cloning and localization of the cGMP-specific phosphodiesterase type 9 in the rat brain. J Neurocytol 31:729-741.

Van Staveren WC, Steinbusch HW, Markerink-Van Ittersum M, Repaske DR, Goy MF, Kotera J, Omori K, Beavo JA, De Vente J (2003) mRNA expression patterns of the cGMP-hydrolyzing phosphodiesterases types 2,5 , and 9 during development of the rat brain. J Comp Neurol 467:566-580.

Vruwink M, Schmidt HH, Weinberg RJ, Burette A (2001) Substance P and nitric oxide signaling in cerebral cortex: anatomical evidence for reciprocal signaling between two classes of interneurons. J Comp Neurol 441:288-301.

Wendland B, Schweizer FE, Ryan TA, Nakane M, Murad F, Scheller RH, Tsien RW (1994) Existence of nitric oxide synthase in rat hippocampal pyramidal cells. Proc Natl Acad Sci USA 91:2151-2155.

Zabel U, Weeger M, La M, Schmidt HH (1998) Human soluble guanylate cyclase: functional expression and revised isoenzyme family. Biochem J 335:51-57.

Zagotta WN, Siegelbaum SA (1996) Structure and function of cyclic nucleotide-gated channels. Annu Rev Neurosci 19:235-263.

Zhuo M, Hu Y, Schultz C, Kandel ER, Hawkins RD (1994) Role of guanylyl cyclase and cGMP-dependent protein kinase in long-term potentiation. Nature 368:635-639.

Zorumski CF, Izumi Y (1998) Modulation of LTP induction by NMDA receptor activation and nitric oxide release. Prog Brain Res 118:173-182. 